\author{
G.K. Asanova ${ }^{1}$, A.Sh. Dodonova ${ }^{1}$, M.Yu. Ishmuratova ${ }^{1}$, W. Push ${ }^{2}$ \\ ${ }^{I}$ Ye.A. Buketov Karaganda State University, Kazakhstan; \\ ${ }^{2}$ Wroclaw University, Poland \\ (E-mail:gulzina_as@mail.ru)
}

\title{
The study of ontogenesis of Centaurea bipinnatifida (Trautv.) Tzvel. in the condition of the city of Karaganda
}

\begin{abstract}
The results of the study of the ontogenesis of Centaurea bipinnatifida in the conditions of introduction of the city of Karaganda are presented in the article. The introduction into the culture of this species is due to the need for its preservation and reproduction in order to obtain biologically active substances. Four age periods (latent, virgin, generative and senile) and nine age states (seedlings, juvenile, immature, adult vegetative, young generative, middle age generative, old generative, sub-senile and senile) have been identified. Morphological features of each period and state, degree of development of above-ground and underground organs are determined. The duration of the small cycle of ontogenesis in the culture of Centaurea bipinnatifida was 3-4 years, in nature - 6-8 years. There has been an excess of crop plants over wild-growing individuals in size. The ontogenesis phases in culture are faster than under natural conditions.
\end{abstract}

Keywords: Centaurea bipinnatifida, ontogenesis, age period, age state, duration, introduction.

\section{Introduction}

One way to rational use and preserve the natural resources of rare, endangered and endemic plant species is to introduce them into culture. Introduction of natural flora species provides extensive material for scientific research, primarily in the field of ontogenesis rhythms. In ex situ conditions, the researcher is able to observe the dynamics of the development of individuals in full, recording the change of age states, which is very difficult to conduct research in the natural condition. The study of ontogenesis makes it possible to estimate the development of plants in different age phases, to determine the duration of vegetation, to assess the effects of climate on the development of above-ground and underground organs in the process [1,2].

In Central Kazakhstan, the interest for introduction is Centaurea bipinnatifida (Trautv.) Tzvel., Asteraceae family), which is a narrow local endemic of the Ulytau Mountains (Ulytau District of Karaganda Region), and can also be sources of biologically active substances [3-5]. This species has a small habitat and is not suitable for raw material harvesting; there is a need for its introduction.

Thus, on the basis of the above, the aim of the study was to investigate the stages of ontogenesis of Centaurea bipinnatifida in the conditions of Karaganda city.

\section{Methodology}

The research was carried out in 2016-2019 in laboratory conditions and on the collection plots of the natural flora of JSC «Scientific and Production Center «Phytochemistry». Seed material was gathered from the mountains of Ulytau (Karaganda region).

Initial stages of ontogenesis were studied under laboratory conditions; further development was analyzed under field conditions. Experimental divisions measuring $2 \times 3 \mathrm{~m}$ were laid on an open untied area; the soil is light chestnut, strongly sandy, weakly paved. During the growing seasons the necessary care (watering, weeding and loosening) was carried out. Growth and development were regularly observed on 30 model plants. Periodization of ontogenesis and determination of age states were carried out according to the literature guidelines [6-9]. Germination of seeds was determined by conventional method [10]. Experiments were laid down in 4-fold repetition, germination energy was determined on the 6th day, seed germination - on the 30th day. When analyzing the features of ontogenesis under culture conditions, the data obtained under nature conditions were taken into account [11].

\section{Results and discussion}

In the ontogenesis of Centaurea bipinnatifida have been identified 4 periods and 9 age states:

1) latent, represented by resting seeds; 
2) virgin, or pre-generative, period, represented the states of seedlings, juvenile, immature and adult vegetative plants;

3) generative period, represented by the states of young, medium-age and old generative plants;

4) senile period, represented by the states of sub-senile and senile plants.

Latent period. The achene of Centaurea bipinnatifida is slightly-clined, pressed, slightly curved, oval in cross-section. The fruit scar is oval, displaced into the side. The surface is smooth, matte, longitudinally ribbed. The colour is from light-brown to dark-brown, lighter in the fruit scar. Seeds have serrated turfs of brown color. The length of the turf is $4 \mathrm{~mm}$ (Fig. 1). Period duration of latent period is 2-3 years.

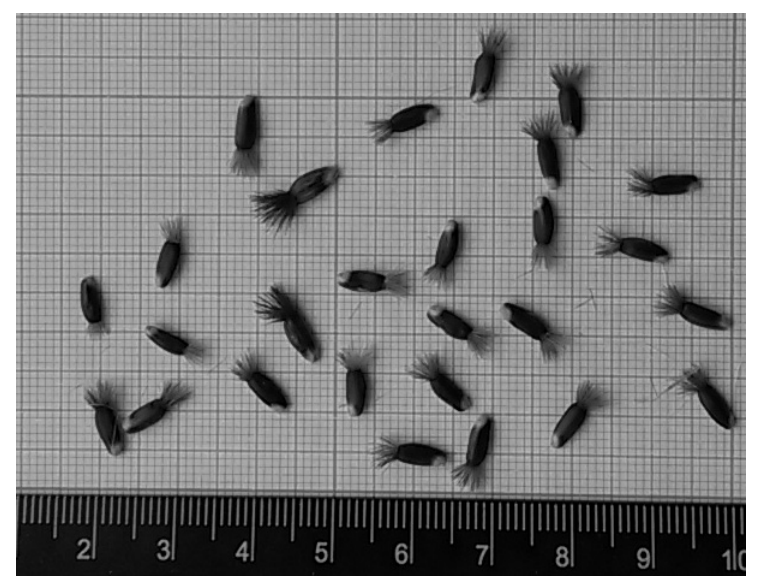

Figure 1. Outward of seeds of Centaurea bipinnatifida

Pre-generative (virgin) period. Seedlings (p). Seeds of 2012, 2013, 2014, 2015 and 2016 years of collection were used to study morphometric and biological indices of the achenes of Centaurea bipinnatifida. Morphometric indices of seeds of different collection years do not differ significantly: length on average is 6.8-8.0 mm, thickness $-0.9-1.0 \mathrm{~mm}$, width $-2.7-3.3 \mathrm{~mm}$. The weight of 1000 seeds ranges from 15.9 to $17.2 \mathrm{~g}$ (Table).

$\mathrm{Tab} l \mathrm{e}$

Morphometric characteristics and germination indices of seeds of Centaurea bipinnatifida of different collection years

\begin{tabular}{|l|c|c|c|c|c|}
\hline \multicolumn{1}{|c|}{$\begin{array}{c}\text { Parameters of quality } \\
\text { of seed material }\end{array}$} & 2014 & 2015 & 2016 & 2017 & 2018 \\
\cline { 2 - 6 } & $7.4 \pm 0.3$ & $6.8 \pm 0.2$ & $7.5 \pm 0.3$ & $8.0 \pm 0.1$ & $7.6 \pm 0.2$ \\
\hline Length, mm & $0.9 \pm 0.1$ & $1.0 \pm 0.1$ & $1.0 \pm 0.8$ & $1.2 \pm 0.1$ & $1.3 \pm 0.2$ \\
\hline Thickness, mm & $2.7 \pm 0.1$ & $3.2 \pm 0.2$ & $3.3 \pm 0.1$ & $3.0 \pm 0.2$ & $3.3 \pm 0.4$ \\
\hline Width, mm & $15.9 \pm 0.2$ & $17.2 \pm 0.1$ & $17.1 \pm 0.3$ & $16.9 \pm 0.2$ & $17.2 \pm 0.1$ \\
\hline Mass of 1000 seeds, g & 0 & $65 \pm 3.2$ & $72 \pm 2.4$ & $62 \pm 2.0$ & $16 \pm 0.3$ \\
\hline Germination energy, \% & 0 & $90 \pm 3.5$ & $90 \pm 3.5$ & $82 \pm 4.1$ & $20 \pm 0.5$ \\
\hline Seed germination, \% & & & & & \\
\hline
\end{tabular}

It was revealed that the seeds of 2014 collection, stored at room temperature, were not viable. Seed material of 2015, 2016 and 2017 years of collection turned out to be with high indicators of germination. Seeds of 2018 collection turned out not to be pre-finished, so germination amounted to $20 \%$. That is, during storage, seeds are heated during 1-2 years of storage, after which viability has gradually reduced.

The biology of germination of the seeds of Centaurea bipinnatifida of laboratory conditions was studied (Fig. 2). The results showed that swelling and seed germination started on 2-3 days after sowing on the Petri dishes. On $4^{\text {th }}$ day after sowing germ roots appeared with desiccation from root hairs. On $7^{\text {th }}$ day a hypocotyl appeared, which made a bend and on $9-10^{\text {th }}$ day there appeared embryo leaves. Leaves appeared complex; opening of embryo leaves took place through 1-2 days. On 15-16-day the seedlings have the first adult leaves. 


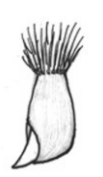

a

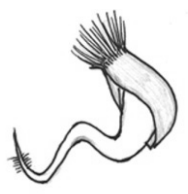

$\mathrm{d}$

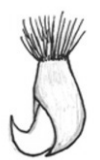

$\mathrm{b}$

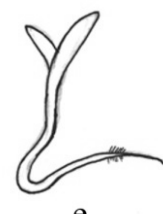

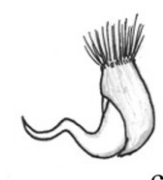

C

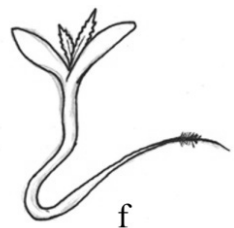

$a$ - beginning of germination; $b$ - appearance of embryo root; $c$ - appearance and bent of hypocotyl; $d$ - appearance of embryo leaves; $e$ - expansion of adult leaves; $f$ - appearance of first pair of adult leaves

Figure 2. Biology of germination of the seeds of Centaurea bipinnatifida

The condition of the seedlings of Centaurea bipinnatifida is represented by individuals with a pair of embryo and a pair of adult leaves. Seedlings height is from 2 to $2.5 \mathrm{~cm}$, diameter is $1-1.6 \mathrm{~cm}$. Duration of this condition is $30-35$ days.

Juvenile individuals (j). Further observations for the plants of Centaurea bipinnatifida were carried out in ground and field conditions. In the ground conditions, plant seeds were planted into a ground mixture with peat and mineral fertilizers.

Juvenile plants formed an initial shoots with 2-3 adult leaves (Fig. 3). The sheet shape is oblong, more often with a whole edge, less - with a paddle. The top of the leaf sheet is pointed, the base is rounded. The color is green, on the lower side it is weakly extinguished (Fig. 4). The root length is $5-8 \mathrm{~cm}$; additional roots of the $1^{\text {st }}$ order appear. Duration of this condition is till 1.5 months.

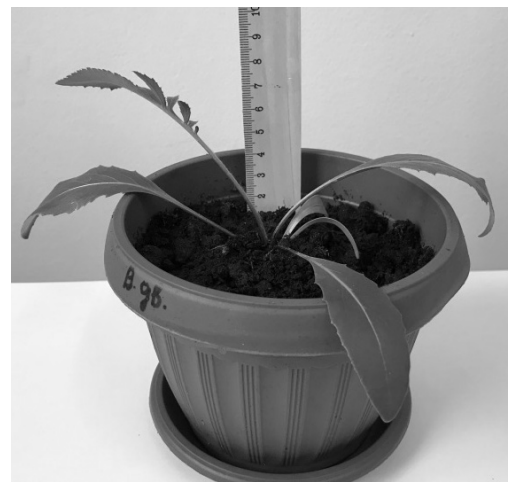

Figure 3. Juvenile plants of Centaurea bipinnatifida in situ condition
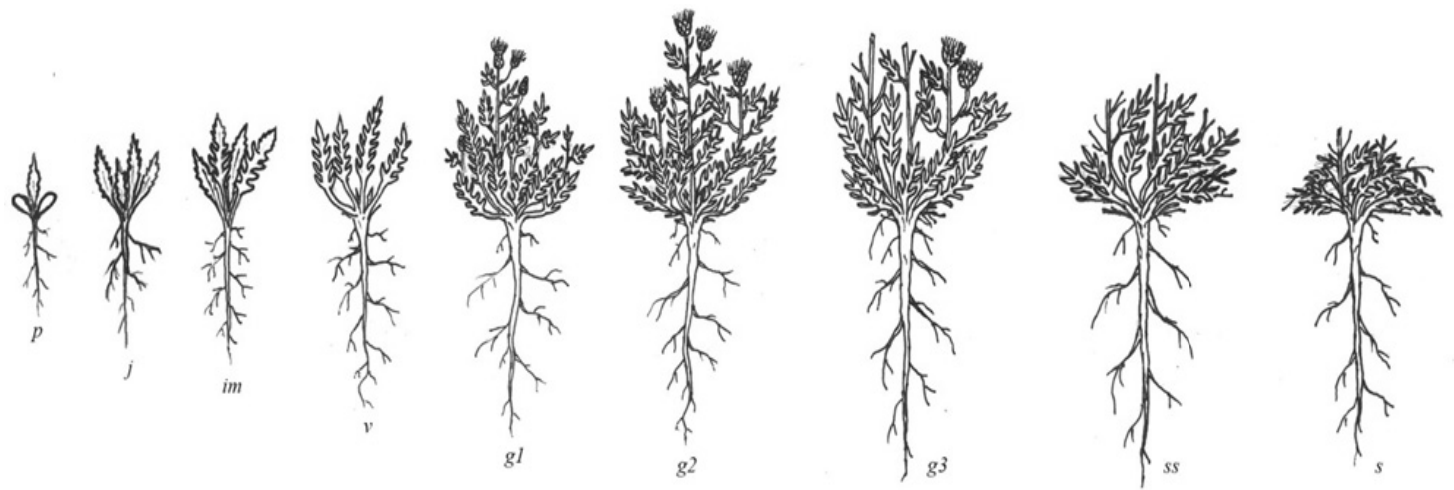

$p$ - seedlings; $j$ - juvenile plants; im — immature plants; $v$ — adult vegetative plants; $g_{l}$ - young generative plants; $g_{2}$ — medium-age generative plants; $g_{3}$ — old generative plants; ss — sub-senile plants; s — senile plants

Figure 4. Ontogenetic states of Centaurea bipinnatifida in culture conditions 
Immature plants. $1^{\text {st }}, 2^{\text {nd }}$ and $3^{\text {rd }}$ adult leaves have a lancet forms; starting from the 4 th, the sheet plate is pinnate-separated from the upper lancet lobe. This aspect characterizes an immature age state. Edges of sheet plate are coarse-sawing (Fig. 5). During this period, the death of the embryo leaves was observed (Fig. 6). The height of plants is $10-12 \mathrm{~cm}$, the diameter of the above-ground mass is up to $15 \mathrm{~cm}$, the length of the root is $10-11 \mathrm{~cm}$. The duration of the state is $40-60$ days.
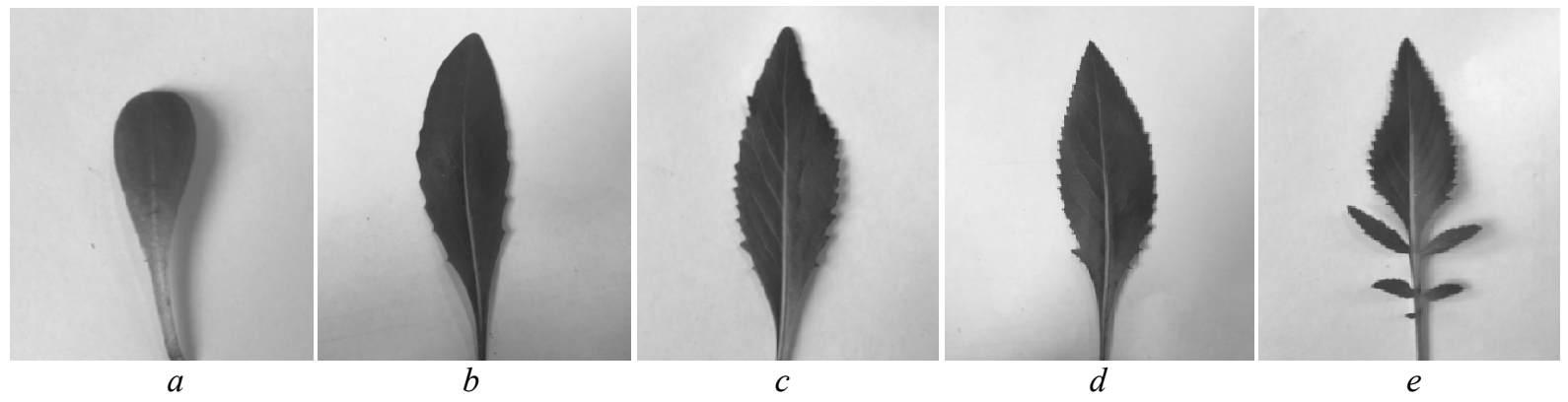

$a$ - embryo leaf; adult leaves: $b$ - I-st leaf; $c$ - II-nd leaf; $d$ - III-rd leaf; $e$ - IV-th leaf

Figure 5. Types of leaves of Centaurea bipinnatifida during process of development

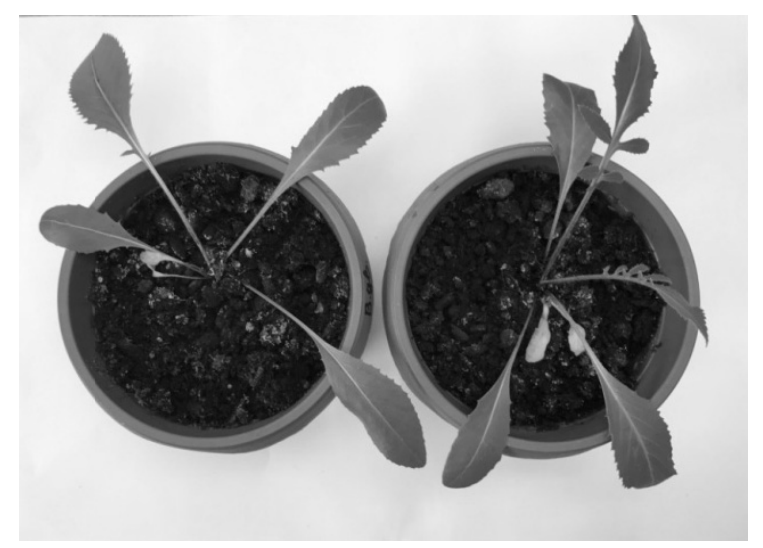

Figure 6. Die-off of embryo leaves of Centaurea bipinnatifida

Further studies of ontogenesis were carried out at the collection site.

Adult vegetative plants. The transition to this age state is marked by the end of the 1 st year of vegetation. Plants form large rosettes of leaves; all leaves are pinnate-dissected or part of them is bi-pinnatedissected with narrow cartilage-sharp-toothed slices. The leaves of adult vegetative individuals are wider and longer than those of the immature type, up to $10-16 \mathrm{~cm}$ long and up to $4 \mathrm{~cm}$ wide. Root system deepens by $15-18 \mathrm{~cm}$, forms multiple lateral roots of the 2 nd order. By the end of the first year of life, renewal buds are formed in the sinuses of the lower leaves of the rosette.

Generative period. Young generative plants. For the second year, Centaurea bipinnatifida change into a young generative state, its growth comes in middle of April. Leaf deployment takes place by the end of April. The leaves are bi-pinnate-dissected with narrow cartilage-sprouted slices up to $26 \mathrm{~cm}$ long and up to 5 $\mathrm{cm}$ wide. Plants form the first generative shoot arising from the upper bud. The height of the first colorbearing shoot is slightly less than that of medium and old generative individuals. The prolific shoots are obnoxious, loosely branching and carry only a few flower baskets. The leaves on the shoots are short-skull. In the base of generative shoot in sinuses of prunes leaves there are buds of renewal, from which one or two for the following year give rise to generative shoots. The root system penetrates deep to $25 \mathrm{~cm}$, from the main root there are lateral, which together with the main root form the main skeleton of the underground part of the plant. Caudex, 1-3-headed, one-piece is formed in the area of root neck. The duration of the condition is 3-4 years.

Medium-age generative plants. In this state, the plants had a well-developed caudex, from which several generative shoots depart, reaching an altitude of up to $110 \mathrm{~cm}$. The shoots touch into growth at the end of 
April and continue until the first decade of July. First, second and third order branches are formed on the fetal shoots (Fig. 4). The number of baskets on the shoot is 5-7 pieces, in each on average 69-72 flowers. In baskets, the first flowers are revealed in the first decade of June, and ends flowering is in the second decade of July, when the last flowers in baskets on third-order shoots blossom. Basket diameter is $2-2.5 \mathrm{~cm}$. Seed productivity is $300-400$ pieces of seeds per plant. The binding ratio of seeds is $40 \%$. The plant forms a developed multi-headed caudex, from which 8-12 generative and 5-6 vegetative shoots leave. The diameter of the root neck increases to $1.2-1.5 \mathrm{~cm}$. The main root deepens to $30 \mathrm{~cm}$. The duration of the condition is 5-6 years.

Old generative plants are characterized by lower growth rates. Individuals are characterized by a sharp decrease in reproductive function, weakening of processes of beat - and root formation. Death processes are beginning to prevail over neoplasm processes, and disintegration is increasing. Thus, there is a decrease in the number of generative shoots to $4-6$, vegetative to $2-3$ pieces. The number of baskets per shoot is $2-3$ pieces. Caudex is divided into 2-3 parts. Plants are in this state for 3-4 years.

Senile period. Sub-senile state. Sub-senile plants of Centaurea bipinnatifida are characterized by termination of fruiting, reduction of power, strengthening of destructive processes, weakening of connection between sprout and root systems, possible simplification of life shape, appearance of immature leaves (Fig. 4). Often parts of the venomous rosettes of leaves remain from the plant. In some individuals there has been a partial die-off of the upper root and a decay of the caudex; plants are represented only by rosette forms. Period duration $2-4$ years.

Senile state. Senile plants of Centaurea bipinnatifida are characterized by extreme fragility, reduction of size, at resumption few buds are realized, secondary appearance of some juvenile traits (shape of leaves, character of shoots, etc.) (Fig. 4). Period duration is 1-3 years.

The study of Centaurea bipinnatifida in culture has shown that its species features are preserved. The plant is a mountain xerophyte combining xeromorphicity with high plasticity under culture conditions. The plant has better growth and development rates in culture than natural growth sites.

Periods and states of ontogenesis of the individual of Centaurea bipinnatifida pass under conditions of culture faster. Thus, under the conditions of nature, plants undergo a complete cycle of ontogenesis for $27-$ 35 years. Small cycle of plant ontogenesis in culture conditions takes place in $3-4$ years, in nature is in 6-8 years.

The experience of introduction of Centaurea bipinnatifida shows the possibility of cultivation and reproduction of this endemic plant.

\section{Conclusion}

Thus, the basic periods and states of the ontogenesis of Centaurea bipinnatifida are determined in the conditions of culture (the city of Karaganda). There are described 4 age periods (latent, virgin, generative and senile) and 9 age states (seedlings, juvenile, immature, adult vegetative, young generative, middle-age generative, old generative, sub-senile and senile). The duration of the small cycle of ontogenesis in culture was 3-4 years, in nature $-6-8$ years. The excess of morphological indices in the conditions of culture compared to nature shows the success of the introduction of this species.

\section{References}

1 Павлова M.А. Особенности онтогенеза Carex divulsa Stokes в условиях культуры на юго-востоке Украины / М.А. Павлова // Промышленная ботаника. — 2014. — Вып. 14. - С. 174-180.

2 Ткаченко К.Г. Взаимодополняющие методы изучения и сохранения редких и полезных растений в условиях еx situ и in situ / К.Г. Ткаченко // Научные ведомости. Сер. естеств. науки. — 2010. — № 9 (80). - Вып. 11. — С. $25-32$.

3 Флора Казахстана. — Т. 9. - Алма-Ата: Наука, 1966. — 546 с.

4 Ишмуратова М.Ю. Флора гор Улытау (Центральный Казахстан) / М.Ю. Ишмуратова, Г.Ж. Мырзалы, В.И. Ивлев, А.Н. Матвеев. - Караганда: Болашак-Баспа, 2016. - 127 с.

5 Ишмуратова М.Ю. Эндемичные виды растений флоры Карагандинской области (Центральный Казахстан) / М.Ю. Ишмуратова, С.У. Тлеукенова, А.Ш. Додонова, Е.А. Гаврилькова. — Караганда: Полиграфист, 2016. — 109 с.

6 Работнов Т.А. Жизненный цикл многолетних травянистых растений в луговых ценозах / Т.А. Работнов // Труды БИН АН СССР. Сер. Геоботаника. — М.; Л.: Изд-во АН СССР, 1959. — С. 204-235.

7 Уранов А.А. Возрастной состав популяций / А.А. Уранов // Ценопопуляция растений. - М.: Наука, 1976. — 645 с.

8 Сикура И.И. Рекомендации по изучению онтогенеза интродуцированных растений в ботанических садах / И.И. Сикура, Л.П. Сырица. - Киев: Наук. думка, 1990. - 185 с. 
9 Игнатьева И.П. Онтогенетический морфогенез вегетативных органов травянистых растений / И.П. Игнатьева. — М.: Изд-во МГУ, 1983. - 55 с.

10 Зорина М.С. Определение семенной продуктивности и качества семян интродуцентов / М.С. Зорина, С.П. Кабанов // Методики интродукционных исследований в Казахстане. - Алма-Ата: Наука, 1987. - С. 75-85.

11 Ишмуратова М.Ю. Онтогенез василька двоякоперистого в условиях гор Улытау (Центральный Казахстан) / М.Ю. Ишмуратова, Г.Ж. Мырзалы, С.У. Тлеукенова, Е.А. Гаврилькова, А.Ш. Додонова // Приволж. науч. вестн. - 2017. № 3 (67). - C. 14-17.

\title{
Г.Қ. Асанова, А.Ш. Додонова, М.Ю. Ишмуратова, В. Пуш \\ Centaurea bipinnatifida (Trautv.) Tzvel. өсімдігінің онтогенезін Қарағанды қаласының дақылдық жағдайында зерттеу
}

\begin{abstract}
Мақалада салалы гүлкекіре өсімдігінің Қарағанды қаласына жерсіндіру жағдайындағы онтогенезін зерттеу нәтижелері көрсетілген. Берілген түрді дақылға енгізуге, биологиялық белсенді заттар алу үшін оны сақтау және көбейту қажеттігі себеп болып отыр. Өсірудің 4 жастық кезеңі (латентті, виргинильді, генеративті және сенильді) және 9 жастық күйі (өскіндер, ювенильді, имматурлық, ересек вегетативті, жас генеративті, орта жас генеративті, қартайған генеративті, субсенильді және сенильді) айқындалған. Әр кезеңнің және күйінің морфологиялық ерекшеліктері, жерүсті және жерасты мүшелерінің даму дәрежесі анықталған. Салалы гүлкекіренің дақылдағы онтогенезінің кіші айналымының ұзақтығы 3-4 жылды, табиғатта - 6-8 жылды құрады. Дақылдағы өсімдіктердің табиғаттағы өсімдіктерге қарағанда габитусы үлкендеу болды. Онтогенез фазалары дақылда табиғи жағдайға қарағанда тез өтеді деген тұжырым жасалды.
\end{abstract}

Кілт сөздер: салалы гүлкекіре, онтогенез, жастық кезең, жастық күйі, ұзақтығы, жерсіндіру.

\author{
Г.К. Асанова, А.Ш. Додонова, М.Ю. Ишмуратова, В. Пуш \\ Изучение онтогенеза Centaurea bipinnatifida (Trautv.) Tzvel. \\ в условиях культуры города Караганды
}

\begin{abstract}
В статье представлены результаты исследования онтогенеза василька двоякоперистого в условиях интродукции города Караганды. Введение в культуру данного вида обусловлено необходимостью его сохранения и размножения для получения биологически активных веществ. Выявлены 4 возрастных периода (латентный, виргинильный, генеративный и сенильный) и 9 возрастных состояний (проростки, ювенильное, имматурное, взрослое вегетативное, молодое генеративное, средневозрастное генеративное, старое генеративное, субсенильное и сенильное). Определены морфологические особенности каждого периода и состояния, степень развития надземных и подземных органов. Продолжительность малого цикла онтогенеза в культуре василька двоякоперистого составила 3-4 года, в природе - 6-8 лет. Отмечено превышение культурных растений над дикорастущими особями по габитусу. Сделан вывод о том, что фазы онтогенеза в культуре проходят быстрее, чем в природных условиях.
\end{abstract}

Ключевые слова: василек двоякоперистый, онтогенез, возрастной период, возрастное состояние, продолжительность, интродукция.

\section{References}

1 Pavlova, M.A. (2014). Osobennosti ontoheneza Carex divulsa Stokes v usloviiakh kultury na yuho-vostoke Ukraini [Peculiarities of ontogenesis of Carex divulsa Stokes in the condition of south-east of Ukraine]. Promyshlennaia botanika - Industrial Botany, 14, 174-180 [in Russian].

2 Tkachenko, K.G. (2010). Vzaimodopolniaiushchie metody izucheniia i sokhraneniia redkikh i poleznykh rastenii v usloviiakh ex situ i in situ [Complementary methods for the study and conservation of rare and useful plants in ex situ and in situ]. Nauchnye vedomosti. Seriia Estestvennye nauki - Scientific Bulletin, series natural Sciences, 9 (80), 11 [in Russian].

3 Flora Kazahstana - Flora of Kazakhstan (1966). Alma-Ata: Nauka [in Russian].

4 Ishmuratova, M.Yu., Myrzaly, G.Zh., Ivlev, V.I. \& Matveev, A.N. (2016). Flora hor Ulytau (Tsentralnyi Kazakhstan) [Flora of Ulytau Mountains (the Central Kazakhstan)]. Karaganda: Bolashak-Baspa [in Russian].

5 Ishmuratova, M.Yu., Tleukenova, S.U., Dodonova, A.Sh. \& Gavrilkova, E.N. (2016). Endemichnye vidy rastenii flory Karahandinskoi oblasti (Tsentralnyi Kazakhstan) [Endemic plant species of Karagandy Region (the Central Kazakhstan)]. Karaganda: Polygraphist [in Russian]. 
6 Rabotnov, T.A. (1959). Zhiznennyi tsikl mnoholetnikh travianistykh rastenii v luhovykh tsenozakh [Life circle of the perennial herbaceous plants in meadow cenoses]. Trudy Botanicheskoho instituta Akademii nauk SSSR. Seriia Heobotanika - Works of Botanical Institute of Academy of Science of USSR, Series Geobotany, Moscow-Leningrad: Izdatelstvo Akademii nauk SSSR [in Russian].

7 Uranov, A.A. (1976). Vozrastnoi sostav populiatsii [Age composition of populations]. Tsenopopuliatsiia rastenii Coenopopulations of plants, Moscow: Nauka [in Russian].

8 Sikura, I.I. \& Syryca, L.P. (1990). Rekomendatsii po izucheniiu ontoheneza introdutsirovannykh rastenii $v$ botanicheskikh sadakh [Recommendations for study of ontogenesis of introduced plants in the botanical gardens]. Kiev: Naukova dumka [in Russian].

9 Ignateva, I.P. (1983). Ontoheneticheskii morfohenez vehetativnykh orhanov travianistykh rastenii [Ontogenetic morphogenesis of the vegetative organs of the herbaceous plants]. Moscow: Publ. of Moscow State University [in Russian].

10 Zorina, M.S., \& Kabanov, S.P. (1987). Opredelenie semennoi produktivnosti i kachestva semian introdutsentov [Determination of seed productivity and quality of the seeds of the introduced plants]. Metodiki introduktsionnykh issledovanii v Kazakhstane Methodology of introduction study in the Kazakhstan. Alma-Ata: Nauka [in Russian].

11 Ishmuratova, M.Yu., Myrzaly, G.Zh., Tleukenova, S.U., Gavrilkova, E.N. \& Dodonova, A.Sh. (2017). Ontohenez vasilka dvoiakoperistoho $\mathrm{v}$ usloviiakh hor Ulytau (Tsentralnyi Kazakhstan) [The ontogenesis of Centaurea bippinatifida in the conditions of Ulytau Mountains (the Central Kazakhstan). Privolzhskii nauchnyi vestnik — Volga Scientific Bulletin, 3(67), 14-17 [in Russian]. 